\title{
Tax Aggressiveness, Fair Value Accounting, Debt Maturity: Does Integrated Reporting Matter?
}

\author{
Pria Aji Pamungkas ${ }^{1}$, Amrie Firmansyah ${ }^{2}$, Resi Ariyasa Qadri ${ }^{3}$, Agung Dinarjito ${ }^{4}$, \\ Zef Arfiansyah ${ }^{5}$ \\ ${ }^{1,2}$ Program Diploma IV Akuntansi Sektor Publik, Politeknik Keuangan Negara STAN \\ 3,4,5 Program Diploma III Akuntansi, Politeknik Keuangan Negara STAN \\ Email Address: \\ priaajipamungkas@gmail.com, amrie@pknstan.ac.id, resi.ariyasa@gmail.com, \\ agungdije@gmail.com,zef.arfiansyah@pknstan.ac.id
}

\begin{abstract}
This study investigates the association between tax aggressiveness, fair value accounting and debt maturity and whether Integrated Reporting (IR) moderates those relationships. This study's methodology is a quantitative approach with multiple linear regression models and panel data. The sample employed in this study is manufacturing companies listed on the Indonesia Stock Exchange (IDX). The type of data used is secondary data sourced from financial statements and annual reports from 2016 to 2020. The sample selection using a purposive sampling method with the number of samples amounted to 595 firm-year observations. This study suggests that tax aggressiveness and fair value accounting have an inverse association with debt maturity. However, IR failed to weaken the negative impact of extensive fair value accounting on debt maturity. The Financial Services Authority (OJK) can consider this study to improve supervision and regulation for better creditor protection through the company's optimal debt maturity policy.
\end{abstract}

Keywords: Debt maturity, fair value accounting, integrated reporting, tax aggressiveness.

Abstrak: Penelitian ini bertujuan untuk membuktikan secara empiris pengaruh agresivitas pajak dan penerapan akuntansi nilai wajar terhadap maturitas utang serta peran Integrated Reporting (IR) dalam memoderasi pengaruh tersebut. Penelitian ini merupakan penelitian kuantitatif dengan analisis regresi data panel. Sampel penelitian sebanyak 119 perusahaan manufaktur yang terdaftar di BEI selama kurun waktu 2016-2020 yang dipilih melalui metode purposive sampling sehingga diperoleh 595 observasi. Hasil penelitian ini menunjukkan bahwa agresivitas pajak dan penerapan akuntansi nilai wajar berpengaruh negatif terhadap maturitas utang. Pada perusahaan yang menerapkan kebijakan agresivitas pajak yang lebih tinggi, penyajian informasi melalui IR dapat meningkatkan tingkat maturitas utang. Namun, IR tidak berhasil memperlemah pengaruh negatif penerapan akuntansi nilai wajar terhadap maturitas utang. Hasil penelitian ini dapat menjadi bahan pertimbangan bagi Otoritas Jasa Keuangan (OJK) untuk meningkat kan pengawasan dan regulasi demi perlindungan kreditur yang lebih baik melalui pengungkapan kebijakan maturitas utang yang optimal dari perusahaan.

Kata kunci: Maturitas utang, agresivitas pajak, akuntansi nilai wajar, integrated reporting. 


\section{INTRODUCTION}

The firm's capital structure decision is irrelevant under the perfect capital market theory (Modigliani and Miller, 1958). However, market imperfections such as information asymmetry (Myers, 1984), taxes (Modigliani and Miller, 1963), and agency problems (Jensen and Meckling, 1976; Myers, 1977) make optimal financing decisions important for companies. Of the various attributes of debt contract instruments, debt maturity is an essential factor to consider (Jordan, 2018). From the company's perspective, debt maturity serves to overcome the costs caused by those market imperfections. The choice of debt maturity that is less than optimal can increase rollover risk, greater interest rate fluctuations and affect a company's growth (Orman and Köksal, 2017).

The strong maturity mismatch caused by financing long-term investments using a significant amount of short-term liabilities is one of the main factors explaining the financial crisis in 2007-2009 (Boubaker et al., 2019). A substantial proportion of short-term debt ownership in a company tends to be identified as underperforming by lenders (Manuelli, 2019). After the 2007 Financial Crisis, the rate of return on bonds issued by companies increased drastically due to many companies experiencing maturity mismatches (Huang et al., 2018). This significant increase in the expected rate of return resulted in the greater cost of debt; hence the company's access to long-term financing would be more challenging.

Debt maturity can be an important instrument to reduce agency costs derived from debt financing activities (Adachi-Sato and Vithessonthi, 2019). An optimal debt maturity structure can mitigate agency problems between creditors and managers. When drafting debt contracts, determining debt maturity can mitigate risk-shifting, underinvestment, and overinvestment problems (Casino-Martínez et al., 2019). Shorter debt maturity can reduce agency problems because creditors regularly supervise more debt contract renegotiation. In addition, creditors prefer to provide short-term debt than long-term debt because the company's default risk will be smaller (Boubaker et al., 2019). However, a longer debt maturity will be more advantageous for the company. Companies will be more protected from cash volatility risks and will not need to renew debt contracts every year (Jordan, 2018). These differences in interests can increase the risk of a maturity mismatch and trigger bankruptcy risk (Wang et al., 2020).

When the debt matures, the increased default risk can occur due to the maturity mismatch, especially for companies experiencing liquidity problems (Chen et al., 2021). The debt maturity structure policy is crucial for managers to pay attention to due to differences in interests and preferences between shareholders and debtholders when companies carry out debt contracts (Manuelli, 2019). Determining optimal debt maturity can impact a company's production and investment levels (Jungherr \& Schott, 2020). However, previous studies still have inconsistencies regarding the optimal debt maturity structure to reduce agency costs (Della Seta et al., 2020). In addition, the market (especially creditors and debt investors) responds to the non-optimal structure of corporate debt maturity with higher expected returns, thereby increasing the company's cost of debt (Cortina et al., 2018). As a result, access to additional funds through debt instruments will become more difficult. It also could impact inadequate company growth. Therefore, the debt maturity is worth noting for further investigation.

The financial and economic literature has long recognized that debt contract design can be used as a tool to reduce shareholder-debt-holder agency conflict (Casino-Martínez et 
al., 2019). Agency conflict between shareholders and debtholders is directly affected by the quality of financial reporting, as more transparent financial reporting reduces the benefits of debt holder information and facilitates efficient monitoring (H. Wang and Zhang, 2017). Firms with lower (higher) financial reporting quality typically face greater (lower) shareholder agency conflicts, resulting in a higher (lower) demand for using certain debt contracting tools as a means to mitigate those conflicts, one of which is through shorter debt maturity (Do, 2020). Therefore, the manager's discretion related to tax aggressiveness and fair value accounting policies can affect the quality of the reported financial statements. Better quality information reported in financial statements is expected to reduce information acquisition costs and the level of information asymmetry by creditors so that the company's access to long-term debt can be more significant.

To what extent have the features of debt contracts changed as tax aggressiveness increased? This question has attracted much attention from tax accounting researchers over the past few years. (Kubick and Lockhart, 2017) examined the association between tax aggressiveness policies and debt maturity structure. Companies that are more aggressive in fulfilling their tax obligations tend to have debt with shorter maturities. This finding aligns with (Platikanova, 2017), who concluded that creditors are more likely to provide shortterm loans to companies that do tax avoidance more aggressively. (Kurniawati and Arifin, 2017) found that tax reporting aggressiveness of Indonesian public companies is negatively associated with debt maturity. In addition, (Masri and Martani, 2014) argued that tax avoidance would increase the company's cost of debt. Lenders see tax evasion as a risk so that the expected rate of return also increases.

Extensive implementation of fair value accounting, especially those from Level 2 and Level 3 estimates, affects the greater demand for using shorter-maturity debt $(\mathrm{H}$. Wang and Zhang, 2017). (Magnan et al., 2012) argued that a greater reliance on Level 2 and Level 3 fair value inputs led to higher levels of the cost of debt, indicating that reliability issues were mainly driven by Level 2 and Level 3 estimates. In Indonesia, previous studies examined the association of fair value accounting on earnings management (Annisa \& Taqwa, 2020), indications of financial statements manipulation (Palasari, 2018), and audit fees (Nur Apandi, 2017). Examinations on the implementation of fair value accounting to debt maturity have never been conducted in Indonesia. The adoption of IFRS that Indonesia has carried out can affect the company's financial reporting process, specifically PSAK 68 on Fair Value Measurement, which has been in effect since January 1, 2015. Therefore, investigating the implementation of fair value accounting can be performed using Indonesian firm data.

This study investigates the association of tax aggressiveness and fair value accounting on the company's debt maturity policy. There are several differences between this study and previous research. First, in contrast to the analysis of (Kurniawati and Arifin, 2017), which used the effective tax rate to measure tax aggressiveness, this study uses the permanent book-tax difference model by (Frank et al., 2009) modified by (Rachmawati and Martani, 2017). According to (Frank et al., 2009), the measurement of the permanent book-tax difference is more consistent in showing tax avoidance activities through tax shelter, which is an extreme form of tax aggressiveness. Moreover, to the best of our knowledge, our study is one of the first to document the impact of fair value accounting on debt maturity using company data in developing countries, especially Indonesia. 
In addition, this study examines whether Integrated Reporting (IR) accentuates the association of tax aggressiveness and fair value accounting on debt maturity. IR aims to describe information regarding the company's strategy, governance, performance, and prospects in creating firm value in one integrated and comprehensive report (Kustiani, 2016). Sustainable development that is increasingly attracting the attention of companies worldwide has led to the development of sustainable reporting (SR) over the last two decades (Beck et al., 2017); (Mårtensson and Westerberg, 2016). Previous research has shown that SR does not always reflect the company's actual involvement in sustainability (Zaro et al., 2020). The emergence of IR initiated by the IIRC is then considered the latest reporting innovation that can correct the weaknesses of SR (Lai et al., 2016). Proponents of IR believe that IR can promote greater transparency in a company's commitment to sustainability issues by integrating financial and non-financial performance in one unified document (Navarrete-Oyarce et al., 2021).

Before the IR concept was introduced in 2013 by the IIRC, the company issued several separate voluntary reports (e.g., sustainability reports or intellectual capital reports) in addition to mandatory financial statements for information to stakeholders regarding the company's value creation process (C. W. Wang et al., 2020). Separate and overly varied reporting presentations can often lead to an information-overload effect for stakeholders to comprehend (de Villiers et al., 2014). IR is one of the breakthroughs for reducing corporate reporting silos by presenting only one report that connects all financial and non-financial information (Grassmann, 2021; Di Vaio et al., 2020; Cortesi and Vena, 2019). Companies presenting IRs expect to provide stakeholders with a holistic picture of how non-financial capital creates corporate financial value. This coherence and convenience to adopt make IR have greater added value than CSR and SR reports (Landau et al., 2020; Tlili et al., 2019).

Companies can adopt the presentation of information based on the IR framework as a strategy to gain legitimacy (Haji and Anifowose, 2016). Through the presentation of IR, companies can take symbolic or substantive actions or a combination of the two to show the company's existence in public (Vourvachis et al., 2016). There is no specific regulation by the government that requires public companies in Indonesia to present an IR. Therefore, public companies in Indonesia that present IR is still voluntary. The company wants to show the existence of its institution in the public eye so that the company's legitimacy can increase (Dosinta et al., 2017). In companies that present IR, quality financial reporting can significantly reduce the company's debt cost (Muttakin et al., 2020). Higher quality financial reporting complemented by the presentation of IRs can reduce the cost of processing information by creditors in assessing the risks and prospects of the company. In addition, (Grassmann, 2021) argued that the presentation of IR strengthens the positive association between CSR spending and firm value.

Our study provides important contributions theoretically and practically. First, this paper contributes to the emerging literature on debt, debt contracting, and tax aggressiveness. It also empirically examines the argument that creditors are more likely to extend short-term debt to more aggressive tax avoidance companies. Second, this paper extends the fair value accounting line of literature by providing empirical evidence on the association between fair value accounting and public debt contract design, especially debt maturity. It also documents a new consequence of fair value application in the debt market. Third, this paper adds to empirical evidence regarding the emerging issues and roles of IR reporting in Indonesia. Practically, this paper provides policy implications to standard 
setters. It suggests a need for more detailed measurement guidance that helps improve the reliability of specific fair value measures. The management can also use it to determine optimal debt maturity policy. Finally, it can be used as an investment or debt contract's consideration for investors and creditors.

The remainder of this study is organized as follows: The next section discusses the theoretical background and related literature to develop the hypotheses. Section 3 Theoretical Framework, Section 4 - Research Method, Section 5 Results, Section 6 Discussion, and Section 7 - Conclusion.

\section{THEORETICAL REVIEW}

The existence of information asymmetry between the agent and the principal can encourage opportunistic actions and policies by agents, one of which is tax aggressiveness. Tax aggressiveness can be one way for agents to overcome the adverse selection problem (Platikanova, 2017). This problem can result in higher costs for companies to obtain funding from external parties (Della Seta et al., 2020). Debt investors prefer more liquidity and cash flow without sacrificing excessive risk that could result in fines by tax authorities and other litigation costs (Kubick and Lockhart, 2017). Firms that engage in aggressive tax avoidance strategies have less debt but with stricter and more expensive requirements (Hasan et al., 2017).

(Kubick and Lockhart, 2017) found that tax aggressiveness is negatively associated with debt maturity structure. Lenders view increasingly aggressive corporate tax policies as a risk so that they will be more likely to agree to debt contracts in the short term (shorter maturity of debt). From the management side, company managers prefer a longer debt maturity structure because the intensity of monitoring from the principal can be reduced (Jungherr and Schott, 2020). In addition, (Platikanova, 2017) argued that companies that actively engage in tax avoidance have a larger proportion of short-term debt.

Tax aggressiveness will increase agency costs, credit risk, and greater information opacity (Edwards et al., 2016). Organizational complexity and information asymmetry due to aggressive tax planning will affect the quality of the information in financial statements. As a result, the demand for oversight when contracting debt will be more significant for tax aggressive firms. Creditors will prefer to carry out more frequent debt renegotiations to obtain information regarding the company's credit quality during the debt extension process. Based on the description above, the first hypothesis can be formulated:

$\mathbf{H}_{1}$ : Tax aggressiveness is negatively associated with debt maturity.

With agency problems such as underinvestment and asset substitution risks (Myers, 1977; Smith Jr and Warner, 1979), lenders who lack information about the company experience systemic information risk. As a result of this information asymmetry, creditors will charge a higher cost of debt (Magnan et al., 2017). Financial reporting provides information to debtholders regarding the risk and evaluation of the decline in the value of company collateral and information useful in assessing the timing and risk of future cash flows from existing projects and future investments (Huang et al., 2018). Debt investors use the information contained in the financial statements as a tool for debt contracting purposes. 
(Magnan et al., 2017) found that implementing fair value accounting using Level 2 and Level 3 inputs is positively associated with cost of debt. The use of management estimates in the fair value measurement of Level 2 and Level 3 is considered by debt investors as information risk. As a result, debt investors are more likely to set a higher cost of debt. One of the adjustments that can be taken is setting a shorter debt maturity. Furthermore, (Wang and Zhang, 2017) argued that the use of Level 2 and Level 3 fair values are negatively associated with debt maturity. Fair value has a high-reliability issue (Wang and Zhang, 2017). Companies that mostly use Level 2 and Level 3 fair value measurements are more likely to issue convertible debt and short-term debt. However, (Ghanbari et al., 2018) argued that fair value accounting could increase the transparency of the financial statements to reduce agency costs and increase access to longer debt maturities.

Managers tend to take advantage of fair value accounting policies so that creditors' assessment of the company's credit risk is getting better. In this study, the extensive use of fair value can affect the quality of the company's financial reporting used by creditors as the basis for debt contract information. The measurement of fair value inputs based on the manager's professional judgment can encourage opportunistic actions by management, mainly so that companies get lighter and more efficient debt contracts. As a result, the level of information asymmetry between the agent and the principal will be more significant, and creditors will prefer to carry out more routine supervision; one way is through setting a shorter debt maturity. Thus, the second hypothesis of this study is as follows:

H2: Fair value accounting is negatively associated with debt maturity.

In the context of legitimacy theory, companies disclose financial and non-financial information to show the existence of their institutions in the eyes of the public (Dosinta et al., 2018). The public's view of the company's legitimacy is a dynamic concept (Deegan, 2019). Changes in society's expectations can have implications for the behavior of company managers in the policy-making process. Voluntary presentation of IR can increase the public's perspective regarding the legitimacy of activities carried out by the company. One of which is tax aggressiveness.

The legitimacy of a company can be achieved by fostering strong relationships with stakeholders, including creditors (Beck et al., 2017). Companies that tend to avoid tax will try to maintain their legitimacy by disclosing information through IR to maintain the reputation and public trust for the company (Kempers, 2017). The company's policy to carry out tax aggressiveness is seen as a risk by lenders so that they will be more inclined to agree to debt contracts in the short term (Kubick and Lockhart, 2017). Creditors consider companies that actively engage in aggressive tax avoidance to be more at risk of cash flow volatility risk (Edwards et al., 2016), tax audit risk (Saksessia and Firmansyah, 2020), and high risk of information opacity (Balakrishnan et al., 2019).

Tax aggressiveness is considered a risky policy for lenders. In addition, information asymmetry due to tax aggressiveness can affect the quality of the information in financial statements. However, with the presentation of IR, creditors will assess the tax aggressiveness policy as a measurable strategy and will provide value to the company. Therefore, the risk of companies carrying out tax aggressiveness can be reduced by presenting the IR by the company. Based on the description above, the third hypothesis is formulated: 
H3: Integrated Reporting weakens the negative association between tax aggressiveness and debt maturity.

Companies that use ethical language to comprehensively inform the company's condition can encourage the emergence of legitimacy from the public. Companies that voluntarily disclose information about good news and bad news in a balanced way will be responded positively to stakeholders (Venter et al., 2017). Voluntary disclosure of nonfinancial information that describes the company's actions on an ongoing basis is one strategy that can increase the legitimacy of the public (Camilleri, 2018).

Implementation of fair value accounting that uses Level 2 and Level 3 inputs can significantly increase the company's cost of debt (Magnan et al., 2017). The use of management estimates in the fair value measurement of Level 2 and Level 3 is considered by debt investors as information risk. Furthermore, (Wang and Zhang (2017) show that fair value is a difficult issue to have a low level of reliability. Companies that use more Level 2 and Level 3 fair value measurements are more likely to issue convertible debt and shortterm debt.

Management estimates in applying fair value accounting using Level 2 and Level 3 inputs pose an information risk for creditors. The presentation of financial statements that use many estimates will make creditors increase their supervision, one of which is with a shorter debt maturity so that creditors can evaluate the credit risk of the company receiving the company more routinely. Creditors see companies that present financial and nonfinancial information through IR to be more transparent in the management of their companies. With the presentation of the IR, the information risk for companies that implement fair value accounting extensively will be reduced so that creditors can provide longer debt maturities. Thus, the fourth hypothesis of this study is as follows:

H4: Integrated Reporting weakens the negative association between fair value accounting and debt maturity.

\section{METHODS}

This research is a quantitative method using purposive sampling in the sample selection process. The selected sample is a manufacturing company that is consistently listed on the IDX during 2016-2020 and presents complete financial statement data and annual reports related to the variables used in the study. The observation period for this research is based on the implementation of PSAK 68 (2015) concerning Fair Value Accounting since September 7, 2015, and regulations regarding annual report obligations as regulated in Per OJK No. 29/POJK.04/2016. 
Table 1. Research sample

\begin{tabular}{lc}
\hline \multicolumn{1}{c}{ Criteria } & Amount \\
\hline Manufacturing companies listed on the IDX as of July 2021 & 195 \\
Manufacturing companies listed on the IDX after January 1, 2015 & $(59)$ \\
Companies that do not present complete annual reports & $(15)$ \\
Companies that have incomplete data for the period 2016 s.d. 2020 & $(2)$ \\
Number of samples & 119 \\
Year & 5 \\
Total observations & 595
\end{tabular}

Source: Processed

The dependent variable in this study is Debt Maturity (DM). This study employs a model from previous studies to measure DM as in the research of (VanKhanh and Hung, 2020), (Rey et al., 2020), (Maurice et al., 2020), (Olibe et al., 2019), and (De Meyere et al., 2018). The following formula measures DM:

$$
\mathrm{DM}=\frac{\text { Long term liabilities }}{\text { Total liabilities }}
$$

Tax aggressiveness is measured using the permanent discretionary book-tax difference (DTAX). (Frank et al., 2009) argue that the permanent book-tax difference is better than other measures because its measure can be more consistent in showing tax shelter activity (a more severe form of tax avoidance). This study will use the DTAX measurement, adapted to Indonesian conditions by (Rachmawati and Martani, 2017).

$$
\text { PERMDIFF }_{\text {it }}=\beta_{0}+\beta_{1} \text { INTANG }_{\text {it }}+\beta_{2} \Delta \text { NOL }_{\text {it }}+\beta_{3} \text { LAGPERM }_{\text {it }}+\varepsilon_{\text {it }}
$$

Fair value accounting is measured by the percentage of financial assets measured at fair value to total assets for the company $i$ at the end of fiscal year $t$. This proxy is the model used by (Adwan et al., 2020) (Xie, 2016). The FV variable is calculated as follows:

$\mathrm{FV}_{\mathrm{it}}=\frac{\text { Total Financial Assets Measured at Fair Value }}{\text { Total Asset }}$

The moderating variable is the disclosure of Integrated Reporting elements. The IR variable is measured by how much conformity of information disclosure in the annual report with the IR Framework by IIRC (International Integrated Reporting Council). Content analysis was done using an IR checklist based on the 2013 IR framework as (Herath and Gunarathne, 2016), (Tesalonika, 2020), (Jayasiri, 2020) and (Cooray et al., 2021).

$\mathrm{IR}_{\mathrm{it}}=\frac{\text { Total score disclosed by the company }}{\text { Total number of criteria in the IR framework guidelines }}$

This study uses three control variables: size, leverage, and maturity of assets. The firm size variable is measured by the natural logarithm proxy (ln) of total assets; this proxy follows the research of (VanKhanh and Hung, 2020), (Rey et al., 2020) and (Van et al., 
2019). Model 1 is used to examine the effect of tax aggressiveness and fair value accounting on debt maturity.

$$
\mathrm{DM}_{\mathrm{it}}=\beta_{0}+\beta_{1} \mathrm{DTAX}_{\mathrm{it}}+\beta_{2} \mathrm{FV}_{\mathrm{it}}+\beta_{3} \mathrm{LEV}_{\mathrm{it}}+\beta_{4} \mathrm{SIZE}_{\mathrm{it}}+\beta_{5} \mathrm{AM}_{\mathrm{it}}+\varepsilon_{\mathrm{it}}
$$

Meanwhile, to analyze the role of IR in moderating the association between independent variables and debt maturity, model 2 is used as follows:

$$
\begin{aligned}
& \mathrm{DM}_{\mathrm{it}}=\beta_{0}+\beta_{1} \mathrm{DTAX}_{\mathrm{it}}+\beta_{2} \mathrm{FV}_{\mathrm{it}}+\beta_{3} \mathrm{LEV}_{\mathrm{it}}+\beta_{4} \mathrm{SIZE}_{\mathrm{it}}+\beta_{5} \mathrm{AM}_{\mathrm{it}}+\beta 6 \mathrm{IR}_{\mathrm{it}}+\beta 7 \mathrm{DTAX} \text { it } * \mathrm{IR}_{\text {it }} \\
& \text { Where: }
\end{aligned}
$$

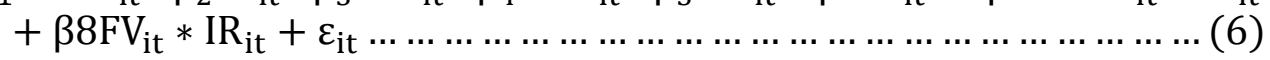

$$
\begin{aligned}
& \mathrm{DM}_{\mathrm{it}} \quad=\text { debt maturity of firm } \mathrm{i} \text { in year } \mathrm{t} \\
& \text { DTAX }_{\text {it }} \quad=\text { level of tax aggressiveness of firm } i \text { in year } t \\
& \mathrm{FV}_{\text {it }} \quad=\text { exposure to fair value accounting application of firm } \mathrm{i} \text { in year } \mathrm{t} \\
& \mathrm{IR}_{\mathrm{it}} \quad=\text { Integrated Reporting disclosure index of firm } \mathrm{i} \text { in year } \mathrm{t} \\
& \mathrm{LEV}_{\text {it }} \quad=\text { leverage of firm i year } \mathrm{t} \text { scaled by total assets } \\
& \mathrm{SIZE}_{\mathrm{it}} \quad=\text { firm size } \mathrm{i} \text { in year } \mathrm{t} \\
& \mathrm{AM}_{\mathrm{it}} \quad=\text { maturity of firm i's assets in year } \mathrm{t}
\end{aligned}
$$

\section{RESULTS}

Descriptive statistics for the variables in this study are listed in Table 2.

Table 2. Descriptive Statistics

\begin{tabular}{ccccccc}
\hline Variable & Obs. & Mean & Median & Std. Dev & Max. & Min. \\
\hline DM & 595 & 0.3246 & 0.2914 & 0.2193 & 0.9727 & 0.0000 \\
DTAX & 595 & 0.0024 & -0.0028 & 0.4110 & 2.3487 & -1.1028 \\
FV & 595 & 0.2410 & 0.2221 & 0.1783 & 0.9584 & 0.0000 \\
IR & 595 & 0.5850 & 0.5658 & 0.1123 & 0.9079 & 0.3421 \\
SIZE & 595 & 28.7155 & 28.4822 & 1.5972 & 33.4945 & 25.2156 \\
LEV & 595 & 0.5431 & 0.4778 & 0.5394 & 5.1677 & 0.0119 \\
ASMAT & 595 & 8.0969 & 5.9548 & 9.7915 & 121.7468 & 0.5417 \\
\hline
\end{tabular}

Source: processed

Furthermore, the results of regression model selection tests (Chow test, Lagrange multiplier test, Hausman test) suggest that the most appropriate regression model in this research is a random-effect model (REM). The result of equation model regression is as follows:

Table 3. Equation model regression test results

\begin{tabular}{lccccccc}
\hline \multicolumn{1}{c}{ Variable } & Hypothesis & \multicolumn{3}{c}{ Model 1 } & \multicolumn{3}{c}{ Model 2 } \\
& & Koef. & $\begin{array}{c}\text { t-Stat } \\
\text { t-Stat }\end{array}$ & Prob. & Koef. & Prob. \\
\hline C & & -0.502 & -1.828 & 0.034 & -0.484 & -1.708 & 0.044 \\
DTAX & - & -0.042 & -2.347 & $0.009 * * *$ & -1.020 & -2.238 & $0.002^{* *}$ \\
FV & - & -0.088 & -1.841 & $0.033 * *$ & -0.159 & -0.584 & 0.279
\end{tabular}




\begin{tabular}{|c|c|c|c|c|c|c|c|}
\hline SIZE & & 0.029 & 3.040 & $0.001 * * *$ & 0.029 & 2.918 & $0.001 * * *$ \\
\hline LEV & & -0.004 & -0.148 & 0.441 & 0.004 & 0.021 & 0.437 \\
\hline ASMAT & & 0.001 & 1.720 & $0.008 * * *$ & 0.001 & 1.795 & $0.007 * * *$ \\
\hline IR & & & & & -0.077 & -0.407 & 0.341 \\
\hline DTAX*IR & - & & & & 1.779 & 2.166 & $0.015 * *$ \\
\hline $\mathrm{FV} * \mathrm{IR}$ & - & & & & 0.208 & 0.412 & 0.340 \\
\hline $\mathrm{R}^{2}$ & & & & 0.0539 & & & 0.0704 \\
\hline Adj. $R^{2}$ & & & & 0.0443 & & & 0.0545 \\
\hline F-Stat. & & & & 5.5853 & & & 4.4261 \\
\hline Prob. (F-Stat.) & & & & 0.0000 & & & 0.0000 \\
\hline
\end{tabular}

\section{DISCUSSIONS}

The association between tax aggressiveness and debt maturity. Based on the results of hypothesis testing, tax aggressiveness is negatively associated with a company's debt maturity. This negative association indicates that the higher the level of corporate tax aggressiveness, the lower the proportion of the company's long-term debt. The results of this study are in line with several previous studies which found that tax aggressiveness is negatively associated with debt maturity (Kubick and Lockhart, 2017; Platikanova, 2017). Creditors can choose a debt contract tool in the form of debt maturity to reduce the information asymmetry (Platikanova, 2017). Creditors tend to prefer shorter maturities when information about a company's credit quality is challenging to verify. Compared to longer debt maturities, shorter debt maturities allow updating of information related to the credit quality of borrowing companies so that this information can be considered during the refinancing process for new debt contracts (Kubick and Lockhart, 2017).

Aggressive tax avoidance practices can increase organizational complexity and reduce transparency (Balakrishnan et al., 2019). It can lead to information asymmetry between companies and creditors that is getting bigger. If tax aggressiveness practices lessen the quality of financial information on which debt contracts are based, creditors are likely to increase their monitoring capabilities by renegotiating debt contracts more frequently. In addition, higher uncertainty due to aggressive tax avoidance policies may increase the risk of being audited by tax authorities (Saksessia and Firmansyah, 2020). The company may also bear a higher burden in the future due to underpayment of taxes and sanctions from the tax authorities. As a result, future cash flows, interest, and principal loan payments can be disrupted. Therefore, the tax aggressiveness policy will further encourage the preference of creditors to provide short-term debt to the company.

The complexity of transactions in manufacturing companies and management's motivation in using debt to increase the company's leverage can be considered by creditors when entering into debt contracts, especially regarding debt maturity (Astuti and Aryani, 2017). Companies with a higher level of complexity and risk of being examined by the tax authorities will be responded to by creditors by providing a more significant proportion of short-term debt. The short-term debt facilitates creditors to be more routine in evaluating the company's credit quality during the debt contract extension process (Xu and Li, 2020).

More aggressive tax planning can lead to higher future cash flow volatility (Huang et al., 2018). If future cash flows are more volatile, then tax-evading firms benefit from 
acquiring long-term debt at a lower cost of debt. Therefore, debt maturity accommodates the interests of the supply side (creditors). Managers of tax avoidance companies rationally benefit from using long-term debt, but creditors tend to be more willing to extend shortterm debt (Platikanova, 2017). The results of this study empirically prove that debt maturity is more likely to be chosen by the supply side (creditors) than the demand side (borrowing companies) in the debt market.

The association between fair value accounting and debt maturity. Based on the results of hypothesis testing, fair value accounting is negatively associated with debt maturity. The higher the company's exposure to fair value accounting policies, the lower the company's debt maturity. The results of this study are in line with previous research, which found that fair value accounting is negatively associated with debt maturity (Wang and Zhang, 2017). This study indicates that the extensive use of estimation and management discretion when measuring fair value in manufacturing companies in developing countries are also responded negatively by creditors by providing lower debt maturity.

Information on accounting numbers in financial statements serves as a valuable tool for creditors to assess the financial health and viability of the company (Dvorkin et al., 2020). Based on agency theory, underinvestment and asset substitution problems that can arise during debt contracting causes creditors to face information risk due to information asymmetry (Maurice et al., 2020). As a result, creditors will charge a higher cost of debt as compensation. Such information risk can be reduced if creditors have access to more timely and informative accounting information. One of the company's efforts in presenting relevant and timely information is through fair value accounting (Magnan et al., 2017).

Fair value accounting policy itself is like a "double-edged sword" in terms of its usefulness for financial statements users, especially creditors (Wang and Zhang, 2017). Level 2 and Level 3 fair value inputs have low reliability based on managers' estimates and discretion (Magnan et al., 2017). Once the fair value input involves discretionary, and estimation errors, the comparability of accounting numbers will be more questionable. Fair value input Level 2 uses the quoted price of an identical asset or liability in an active or inactive market (PSAK 68, 2015). However, management has discretion in determining "identical items" for price matching purposes, thus making Level 2 fair value subject to significant reliability issues (Fauzie et al., 2018). The determination of Level 3 fair value inputs is even more discretionary. Level 3 inputs are used when observable market inputs are not available. Determining unobservable inputs involves the company's management assumptions, which raises the question of reliability, comparability, and understanding of Level 3 inputs (Magnan et al., 2015). Therefore, Level 3 inputs can even exacerbate information risk for creditors, which results in reduced creditor confidence in the company.

In Indonesia, the adoption of IFRS rules regarding fair value accounting is regulated in PSAK 68 concerning Fair Value Accounting. PSAK 68 explains that companies must disclose the fair value measurement of their financial assets and liabilities and the measurement procedures. However, based on observations on the financial statements of sample companies, fair value accounting disclosures for manufacturing companies in Indonesia are still very diverse. Only a few companies disclose in detail the fair value accounting assessments of their financial assets, especially for Level 2 and Level 3 fair values. Disclosures that are still diverse and incomplete make investors and creditors unable to assess the quality of fair value presentation by manufacturing companies. 
The ownership of financial assets in manufacturing companies in this study is not very significant. Unlike financial industry companies, financial assets are not one of the primary sources of profit for manufacturing companies. Manufacturing companies prefer stable long-term investments rather than trading short-term financial assets with higher risk (Wu, 2017). The characteristics of fair value accounting policies for manufacturing companies are different from financial companies (Wu, 2017). In general, financial industry companies have significant financial assets, mainly due to managing public funds, which are more liquid. Therefore, the financial industry will be more sensitive to changes in the fair value of its financial assets (Wu, 2017).

Accounting standards in Indonesia provide an opportunity for companies to be able to choose their fair value accounting policies, especially policies for measuring fair value inputs and changes in the valuation of the fair value hierarchy. This discretion can create problems of distortion of accounting numbers and become material for income smoothing actions (Murti and Suyanto, 2017). Compared to historical costs, fair value measurement can result in greater earnings persistence despite a decline in the company's financial performance (Latifatul et al., 2021). The more likely managers are to use their discretion to measure fair value, creditors will view this as an information risk due to the greater level of information asymmetry between managers and creditors (Wang and Zhang, 2017).

The role of integrated reporting on the association between tax aggressiveness and debt maturity. Based on the results of hypothesis testing, the presentation of IR succeeded in weakening the negative association between corporate tax aggressiveness and debt maturity. In the previous discussion, tax aggressiveness is considered a risky policy for creditors so that creditors will tend to provide loans with short-term maturities to increase the supervision of companies. With the presentation of IR, the creditor's judgment on the credit risk of companies that engage in tax aggressiveness can be reduced. The results of this study are in line with (Venter et al., 2017), which shows that disclosure of information through IR can increase the transparency of tax policy disclosure.

Risky tax aggressiveness policies will increase tax audit risk, the number of sanctions and fines paid, and the risk of damaging the company's reputation, especially from creditors (Firmansyah and Bayuaji, 2019). Damage to the trust and legitimacy of the creditor can affect the creditor's assessment during the debt contract so that it can disrupt the company's capital structure. Companies can use a normative/societal legitimacy strategy to mitigate this risk by disclosing more transparent information through IR (Maniora, 2017). Information connectivity in the concept of integrated thinking provides a better perspective for value creation and broadens the scope of corporate reporting (Eccles and Spiesshofer, 2016). In addition, the company's reporting process through IR is one of the mechanisms that can improve corporate governance (Obeng et al., 2020).

The presentation of IR can facilitate a company's strategy to build trust and company reputation through long-term value creation. Trust and reputation are crucial aspects that can affect the company's value (Deloitte, 2015). The integrated reporting process through IR requires managers to explain how the organization's strategy, governance, performance, and prospects lead to value creation in the context of its external environment in the short, medium, and long term (Joshi, 2019). The company's efforts to disclose more information through IR can be a company strategy to gain legitimacy for the policies taken, one of which is an aggressive tax avoidance policy (Dosinta et al., 2018). 
Improvement efforts by management, if not published, will not be able to effectively change public perception (García-Sánchez and Noguera-Gámez, 2018). This perspective encourages the importance of corporate disclosure through integrated reports. Tax aggressiveness policies carried out by companies can cause negative perceptions for creditors, significantly when these policies can increase the risk of being examined by the tax authorities (Landau et al., 2020). Companies that seek to disclose information through IR will apply the concept of integrated thinking, which is considered to limit opportunistic actions by management (Gerwanski, 2020). The number of parties involved in the IR presentation process will encourage the check and balance mechanism of the company's stakeholders, so that company managers will tend to be more careful, especially to avoid too aggressive tax. In addition, IR will make it easier for creditors to assess its credit quality.

Voluntary presentation of IR by Indonesian manufacturing companies is a management effort to be considered more transparent by creditors. Disclosure of IR elements explains how companies can clearly and concisely describe their value creation process with various resources they have (IIRC, 2013). Commitment to presenting IR can be one way to increase the transparency of the company's management (Mervelskemper and Streit, 2017). Furthermore, increasing information transparency through IR can reduce information asymmetry between creditors and management and between creditors and shareholders (Kashefi Pour and Lasfer, 2019). Therefore, the presentation of IR improves creditors' perspective regarding the legitimacy of activities carried out by the company, one of which is the tax aggressiveness policy.

The role of integrated reporting on the association between fair value accounting and debt maturity. Based on the results of hypothesis testing, the presentation of IR did not succeed in weakening the negative association between fair value accounting and debt maturity. Although the presentation of IR can be a good strategy for companies to gain legitimacy, voluntary disclosure of non-numerical information according to the IR concept does not provide more value for creditors and investors (Chariri, 2019). The implementation of integrated thinking under the IR concept is still in its early stages and has not been widely adopted by most companies in Indonesia (Dosinta and Brata, 2020). This study shows that manufacturing companies' quality of IR practices in Indonesia is still highly variable. Some companies have a good level of IR quality while other companies still offer low integration. In addition, the presentation of IRs in Indonesia is still voluntary, and there are no rules requiring disclosure of IR elements (Cheng et al., 2014). It allows creditors to see that the presentation of the IR is only a one-sided claim from the company.

The adoption of financial reporting trends through IR has not been widely applied in Indonesia (Fernando et al., 2018). There are still no regulations or sanctions from the government to encourage companies to present information through the IR approach (Tang, 2017). Financial information used as an indicator in the relevance of IR value is distorted by the application of accounting standards which are relatively the same in pre and post IR adoption (Fernando et al., 2018). The disclosure of non-numerical information in the IR is not significantly related to numerical information in the company's annual report (Bhimantara and Dinarjito, 2021). Voluntary presentation of information through the IR element is considered unable to provide added value information so that creditors and investors are not responding to their policy-making (Kurniawan et al., 2020). 
Furthermore, a survey conducted by (Adhariani and Villiers, 2018) to company report makers, academics, and OJK employees showed that there is still a limited level of understanding of the concept and implementation of IR in Indonesia. The preparers of the company's financial statements paradoxically state that they can see the benefits of IR, but they are reluctant to implement it. The reason is the high cost of implementing IR and the lack of supporting information systems (Naynar et al., 2018). The company's internal processes to combine financial and non-financial information in one integrated report require structural and cultural changes in the decision-making process that are difficult to implement (Dumay and Dai, 2017).

The implementation of IR reporting also faces issues regarding framework adoption, assessment and meanings of capitals, the extent of report contents, assurance complexity, and window dressing problems (Vitolla et al., 2019). IR implementation is difficult because of the lack of consistency between the framework and sustainability principles and difficulties understanding the six categories of capital by users and IR report makers (Benlemlih, 2017). In addition, the breadth of content and the limited focus of IR reports cause problems of standardization and heterogeneity of reported IR content so that IR users have difficulty processing the information provided (Alexander and Blum, 2016). Large amounts of information and the lack of specific information systems and internal controls can make assurance of information disclosed through IRs more complicated and become a one-sided company claim (Stacchezzini et al., 2016). Therefore, the information in the IR, which is a unilateral claim by the company, can only be a formality tool and as a company's window dressing policy to gain public legitimacy (Vitolla et al., 2019).

\section{CONCLUSION}

This study found that tax aggressiveness is negatively associated with debt maturity. Aggressive tax avoidance practices can increase organizational complexity, reduce corporate transparency and lead to higher volatility of future cash flows. Fair value accounting is also negatively associated with debt maturity. Fair value accounting disclosures in manufacturing companies in Indonesia are still less transparent, especially regarding the measurement of their fair value inputs. The more likely managers are to use discretion and their estimates for fair value measurements, creditors will view this as information risk and encourage tighter control.

Integrated Reporting succeeded in weakening the negative association between tax aggressiveness and debt maturity. Creditors respond to reduced information asymmetry from IR disclosure to compensate for the company's liquidity risk due to tax aggressiveness policies. In addition, preparing IR through the integrated thinking process can limit the motivation of managers to act opportunistically. However, IR failed to weaken the negative association between fair value accounting and debt maturity. The company's efforts to present information through IR cannot reduce the information asymmetry that arises from the extensive implementation of fair value accounting policies on debt maturity.

The limitation of this research is that the measurement of the IR variable using the content analysis method independently can lead to subjective assessment. Second, the results of this research cannot be used to generalize the debt maturity behavior of all public companies in Indonesia as it only uses manufacturing company's data. Future research can notably investigate whether the variables in this paper affect other elements of debt contracts 
and how debt maturity is associated with debt covenants and collateral. It also can further explore how company-specific characteristics and macroeconomic factors can affect or moderate the impact of the variables in this study on debt maturity in Indonesia. In addition, further research needs to specify private debt and public debt to understand better the characteristics of debt maturity and its impact on companies and creditors.

Based on the results of this paper, aggressive tax avoidance policies and extensive fair value estimation and discretion by management need to be considered because they can reduce the creditor's willingness to provide long-term loans. Integrated disclosure of information through IR has been shown to reduce information asymmetry between creditors and managers. Regarding fair value measurement, OJK needs to improve regulations so that Indonesian manufacturing companies should disclose in more detail the use of fair value inputs under PSAK 68. Based on this study, companies that are more aggressive in tax avoidance tend to have a more significant proportion of short-term debt. Thus, companies with a large proportion of short-term debt can be used as a red flag in monitoring their tax compliance by the Indonesia Tax Authority.

\section{REFERENCES}

Adachi-Sato, M., and Vithessonthi, C. (2019). Corporate debt maturity and future firm performance volatility. International Review of Economics and Finance, 60, 216-237. https://doi.org/10.1016/j.iref.2018.11.001.

Adwan, S., Alhaj-Ismail, A., and Girardone, C. (2020). Fair value accounting and value relevance of equity book value and net income for European financial firms during the crisis. Journal of International Accounting, Auditing and Taxation, 39, 100320. https://doi.org/10.1016/j.intaccaudtax.2020.100320.

Alexander, D., and Blum, V. (2016). Ecological economics: A Luhmannian analysis of integrated reporting. Ecological Economics, 129, 241-251. https://doi.org/10.1016/j.ecolecon.2016.06.020.

Annisa, R. H., dan Taqwa, S. (2020). Pengaruh fair value accounting dan dewan komisaris terhadap earning management yang dimoderasi oleh peran syariah. Jurnal Eksplorasi Akuntansi, 2(1), 2280-2298. https://doi.org/10.24036/jea.v2i1.212.

Astuti, T. P., dan Aryani, Y. A. (2017). Tren penghindaran pajak perusahaan manufaktur di Indonesia yang terdaftar di BEI tahun 2001-2014. Jurnal Akuntansi, 20(3), 375-388. https://doi.org/10.24912/ja.v20i3.4.

Balakrishnan, K., Blouin, J. L., and Guay, W. R. (2019). Tax aggressiveness and corporate transparency. The Accounting Review, 94(1), 45-69. https://doi.org/10.2308/accr-52130.

Beck, C., Dumay, J., \& Frost, G. (2017). In pursuit of a 'single source of truth': from threatened legitimacy to integrated reporting. Journal of Business Ethics, 141(1), 191205. https://doi.org/10.1007/s10551-014-2423-1.

Benlemlih, M. (2017). Corporate social responsibility and firm debt maturity. Journal of Business Ethics, 144(3), 491-517. https://doi.org/10.1007/s10551-015-2856-1.

Bhimantara, G. R., dan Dinarjito, A. (2021). Pengaruh profitabilitas terhadap nilai perusahaan dengan moderasi pengungkapan elemen-elemen integrated reporting. $E$ Jurnal Akuntansi, 31(4), 996-1009. https://doi.org/10.24843/EJA.2021.v31.i04.p16.

Boubaker, S., Chourou, L., Haddar, M., and Hamza, T. (2019). Does employee welfare affect corporate debt maturity? European Management Journal, 37(5), 674-686. 
https://doi.org/10.1016/j.emj.2019.08.004.

Camilleri, M. A. (2018). Theoretical insights on integrated reporting: The inclusion of nonfinancial capitals in corporate disclosures. Corporate Communications, 23(4), 567581. https://doi.org/10.1108/CCIJ-01-2018-0016.

Casino-Martínez, A., López-Gracia, J., Mestre-Barberá, R., and Peiró-Giménez, A. (2019). An agency approach to debt maturity of unlisted and listed firms in the European setting. European Management Journal, 37(3), 339-352. https://doi.org/10.1016/j.emj.2018.07.008.

Chariri, A. (2019). The patterns of integrated reporting: a comparative study of companies listed on the Johannesburg Stock Exchanges and Indonesia Stock Exchanges. Jurnal Reviu Akuntansi Dan Keuangan, 9(1), 1. https://doi.org/10.22219/jrak.v9i1.8248.

Chen, H., Xu, Y., \& Yang, J. (2021). Systematic risk, debt maturity, and the term structure of credit spreads. Journal of Financial Economics, 139(3), 770-799. https://doi.org/10.1016/j.jfineco.2020.09.002.

Cooray, T., Senaratne, S., Gunarathne, N., Herath, R., and Samudrage, D. N. (2021). Adoption of integrated reporting in Sri Lanka: coverage and trend. Journal of Financial Reporting and Accounting, 19(5), 1-27. https://doi.org/10.1108/JFRA-042020-0116.

Cortesi, A., and Vena, L. (2019). Disclosure quality under integrated reporting: a value relevance approach. Journal of Cleaner Production, 220, 745-755. https://doi.org/10.1016/j.jclepro.2019.02.155.

Cortina Tatiana Didier Sergio L Schmukler, J. J., Kraay, A., Jeanne, O., Soledad Martínez Pería, M., Mayer, C., Pagano, M., Polo, A., Presbitero, A., Popov, A., Reinhart, C., Rudolph, H., Servén, L., Singh, N., and Tressel, T. (2018). Corporate borrowing and debt maturity: market access and crisis effects. https://papers.ssrn.com/sol3/papers.cfm?abstract_id=2849115.

D. Adhariani, and Villiers, C. de. (2018). Integrated reporting: perspectives of corporate report preparers and other stakeholders. Sustainability Accounting, Management and Policy Journal, 10(1), 126-156.

de Villiers, C., Rinaldi, L., \& Unerman, J. (2014). Integrated reporting: Insights, gaps and an agenda for future research. Accounting, Auditing and Accountability Journal, 27(7), 1042-1067. https://doi.org/10.1108/AAAJ-06-2014-1736.

Deegan, C. M. (2019). Legitimacy theory: Despite its enduring popularity and contribution, time is right for a necessary makeover. Accounting, Auditing and Accountability Journal, 32(8), 2307-2329. https://doi.org/10.1108/AAAJ-08-2018-3638.

Della Seta, M., Morellec, E., and Zucchi, F. (2020). Short-term debt and incentives for risktaking. Journal of Financial Economics, 137(1), 179-203. https://doi.org/10.1016/j.jfineco.2019.07.008.

Deloitte. (2015). A Directors' Guide to Integrated Reporting Contents. A Directors ' Guide to Integrated Reporting Contents.

Di Vaio, A., Syriopoulos, T., Alvino, F., and Palladino, R. (2020). "Integrated thinking and reporting" towards sustainable business models: a concise bibliometric analysis. Meditari Accountancy Research, 29(4).

Do, T. K. (2020). Financial statement comparability and corporate debt maturity. Finance Research Letters, March, 101693. https://doi.org/10.1016/j.frl.2020.101693.

Dosinta, N. F., dan Brata, H. (2020). Politik penamaan dalam pelaporan korporat pascaimplementasi integrated reporting. Jurnal Akuntansi Multiparadigma, 11(1), 
138-158. https://doi.org/10.21776/ub.jamal.2020.11.1.09.

Dvorkin, M., Sánchez, J. M., Sapriza, H., and Yurdagul, E. (2020). News, sovereign debt maturity, and default risk. Journal of International Economics, 126. https://doi.org/10.1016/j.jinteco.2020.103352.

Eccles, R. G., and Spiesshofer, B. (2016). Integrated reporting for a re-imagined capitalism. Re-Imagining Capitalism, 207-225. https://doi.org/10.1093/acprof:oso/9780198785453.003.0015.

Edwards, A., Schwab, C., and Shevlin, T. (2016). Financial constraints and cash tax savings. The Accounting Review, 91(3), 859-881. https://doi.org/10.2308/accr-51282.

Fauzie, S., Sugeng, W., and Soeparno, I. (2018). The Relevance of the fair value of securities investment in predicting the income and stock prices of the banking industry in Indonesia. Advances in Social Science, Education and Humanities Research, 292(Agc), 588-594. https://doi.org/10.2991/agc-18.2019.88.

Fernando, K., Dharmawati, R., Sriani, D., Shauki, E. R., \& Diyanty, V. (2018). Does integrated reporting approach enhance the value relevance of accounting information?: evidence from Asian Firms. Advances in Economics, Business and Management Research, 55, 112-117. https://doi.org/10.2991/iac-17.2018.20.

Firmansyah, A., and Bayuaji, R. (2019). Financial constraints, investment opportunity set, financial reporting aggressiveness, tax aggressiveness: Evidence from Indonesia manufacturing companies. Academy of Accounting and Financial Studies Journal, 23(5).

Frank, M. M., Lynch, L. J., and Rego, S. O. (2009). Tax reporting aggressiveness and its relation to aggressive financial reporting. The Accounting Review, 84(2), 467-496.

García-Sánchez, I. M., and Noguera-Gámez, L. (2018). Institutional investor protection pressures versus firm incentives in the disclosure of integrated reporting. Australian Accounting Review, 28(2), 199-219. https://doi.org/10.1111/auar.12172.

Gerwanski, J. (2020). Does it pay off? Integrated reporting and cost of debt: European evidence. Corporate Social Responsibility and Environmental Management, 27(5), 2299-2319. https://doi.org/10.1002/csr.1965.

Ghanbari, M., Hayati, E., Taheri, M., and Kaki, M. (2018). Evaluating the impact of fair value accounting on debt structure and financial reporting of listed companies in Tehran Stock Exchange. Journal of Advanced Pharmacy Education \& Research, 176-180.

Grassmann, M. (2021). The relationship between corporate social responsibility expenditures and firm value: The moderating role of integrated reporting. Journal of Cleaner Production, 285, 124840. https://doi.org/10.1016/j.jclepro.2020.124840.

Haji, A. A., and Anifowose, M. (2016). The trend of integrated reporting practice in South Africa: ceremonial or substantive? Sustainability Accounting, Management and Policy Journal, 7(2), 190-224. https://doi.org/10.1108/SAMPJ-11-2015-0106.

Hasan, I., Hoi, C. K., Wu, Q., and Zhang, H. (2017). Social capital and debt contracting: Evidence from bank loans and public bonds. Journal of Financial and Quantitative Analysis, 52(3), 1017-1047. https://doi.org/10.1017/S0022109017000205.

Herath, and Gunarathne. (2016). Assessing the gap between integrated reporting and current integrated corporate reporting practice: a proposed checklist. https://doi.org/10.13140/RG.2.2.30407.91048.

Huang, Q., Jiang, F., and Wu, S. Y. (Jennifer). (2018). Does short-maturity debt discipline managers? Evidence from cash-rich firms' acquisition decisions. Journal of 
Corporate Finance, 53, 133-154. https://doi.org/10.1016/j.jcorpfin.2018.10.001.

IIRC. (2013). The international integrated reporting framework. https://www.integratedreporting.org/resource/international-ir-framework/.

Jayasiri, N. K. (2020). Integrated reporting in Sri Lanka: An exploratory study [University of Otago]. https://ourarchive.otago.ac.nz/handle/10523/10502.

Jensen, M. C., and Meckling, W. H. (1976). Theory of the firm: Managerial behavior, agency costs and ownership structure. Journal of Financial Economics, 3(4), 305360. https://doi.org/10.1016/0304-405X(76)90026-X.

Jordan, C. O. F. (2018). The determinants of debt maturity: the case of Jordan. Academy of Accounting and Financial Studies Journal, 22(1), 1-13.

Joshi, P. L. (2019). Integrated reporting: current trends in financial reporting. International Journal of Accounting Research, 06(02), 2-5. https://doi.org/10.35248/2472114x.18.6.177.

Jungherr, J., \& Schott, I. (2020). Optimal debt maturity and firm investment. Review of Economic Dynamics, 1, 1-23. https://doi.org/10.1016/j.red.2020.10.005.

Kashefi Pour, E., and Lasfer, M. (2019). Taxes, governance, and debt maturity structure: International evidence. Journal of International Financial Markets, Institutions and Money, 58, 136-161. https://doi.org/10.1016/j.intfin.2018.09.011.

Kempers, W. (2017). The relationship between integrated reporting and corporate tax avoidance. In Amsterdam Business School . https://scripties.uba.uva.nl/search?id=643568.

Kubick, T. R., and Lockhart, G. B. (2017). Corporate tax aggressiveness and the maturity structure of debt. Advances in Accounting, 36, 50-57. https://doi.org/10.1016/j.adiac.2016.10.001.

Kurniawan, B., Refianto, dan Fernando, K. (2020). Penerapan integrated reporting dan kaitannya dengan informasi akuntansi: studi pada perusahaan di kawasan Asia yang terdaftar pada the international integrated reporting council. Jurnal Penelitian Akuntansi, 1(2), 99-114. https://doi.org/10.19166/jpa.v1i2.2773.

Kurniawati, L., dan Arifin, H. (2017). Agresivitas pajak dan maturitas utang. Jurnal Pajak Indonesia, 1(1), 92-106. https://doi.org/10.31092/jpi.v1i1.176.

Kustiani, N. A. (2016). Penerapan elemen-elemen integrated reporting pada perusahaan yang terdaftar di Bursa Efek Indonesia. Info Artha, 3, 44-61. https://doi.org/10.31092/jia.v3i0.38.

Lai, A., Melloni, G., and Stacchezzini, R. (2016). Corporate sustainable development: is "integrated reporting" a legitimation strategy? Business Strategy and the Environment, 25(3), 165-177. https://doi.org/10.1002/bse.1863.

Landau, A., Rochell, J., Klein, C., and Zwergel, B. (2020). Integrated reporting of environmental, social, and governance and financial data: Does the market value integrated reports? Business Strategy and the Environment, 29(4), 1750-1763. https://doi.org/10.1002/bse.2467.

Latifatul, A., Junaidi, J., dan Hariri, H. (2021). Pengaruh fair value accounting, good corporate governance terhadap earning management (studi empiris pada perusahaan manufaktur yang terdaftar di BEI tahun 2017 - 2019). E-JRA FEB Universitas Islam Malang, 10(02), 60-74.

Magnan, M., Menini, A., and Parbonetti, A. (2015). Fair value accounting: information or confusion for financial markets? Review of Accounting Studies, 20(1), 559-591. https://doi.org/10.1007/s11142-014-9306-7. 
Magnan, M., Wang, H., and Yaqi Shi. (2017). Fair value accounting and the cost of debt. https://cirano.qc.ca/files/publications/2016s-32.pdf.

Maniora, J. (2017). Is Integrated Reporting Really the Superior Mechanism for the Integration of Ethics into the Core Business Model? An Empirical Analysisintegrated reporting really the superior mechanism for the integration of ethics into the core business model? an empiri. Journal of Business Ethics, 140(4), 755-786. https://doi.org/10.1007/s10551-015-2874-z.

Manuelli, R. E. (2019). What determines debt maturity? Federal Reserve Bank of St. Louis Review, 101(3), 155-176. https://doi.org/10.20955/r.101.155-76.

Mårtensson, K., and Westerberg, K. (2016). Corporate environmental strategies towards sustainable development. Business Strategy and the Environment, 25(1), 1-9.

Masri, I., and Martani, D. (2014). Tax avoidance behaviour towards the cost of debt. International Journal of Trade and Global Markets, 7(3), 235-249. https://doi.org/10.1504/IJTGM.2014.064911.

Maurice, Y., Mard, Y., and Séverin, É. (2020). The effect of earnings management on debt maturity: An international study. Comptabilite Controle Audit, 26(2), 125-156. https://doi.org/10.3917/cca.262.0125.

Mervelskemper, L., and Streit, D. (2017). Enhancing market valuation of ESG performance: is integrated reporting keeping its promise? Business Strategy and the Environment, 26(4), 536-549. https://doi.org/10.1002/bse.1935.

Modigliani, F., and Miller, M. H. (1958). The cost of capital, corporation finance and the theory of investmient. The American Economic Review, 48(3), 261-297.

Modigliani, F., and Miller, M. H. (1963). Corporate income taxes and the cost of capital: a correction. The American Economic Review, 53(3), 433-443.

Murti, N. W., and Suyanto, S. (2017). The relevance of fair value concept compared to historical costs in Indonesia. In Proceedings Of Indonesia Focus. https://www.indonesiafocus.net/index.php/PIF/article/view/18.

Muttakin, M. B., Mihret, D., Lemma, T. T., and Khan, A. (2020). Integrated reporting, financial reporting quality and cost of debt. International Journal of Accounting and Information Management, 28(3), 517-534. https://doi.org/10.1108/IJAIM-10-2019-0124.

Myers, S. C. (1977). Determinants of corporate borrowing. Journal of Financial Economics, 5(2), 147-175. https://doi.org/10.1016/0304-405X(77)90015-0.

Myers, S. C. (1984). Finance theory and financial strategy. Interfaces, 14(1), 126-137.

Navarrete-Oyarce, J., Gallegos, J. A., Moraga-Flores, H., and Gallizo, J. L. (2021). Integrated reporting as an academic research concept in the area of business. Sustainability (Switzerland), 13(14), 17-19. https://doi.org/10.3390/su13147741.

Naynar, N. R., Ram, A. J., and Maroun, W. (2018). Expectation gap between preparers and stakeholders in integrated reporting. Meditari Accountancy Research, 26(2), 241-262. https://doi.org/10.1108/MEDAR-12-2017-0249.

Nur Apandi, R. N. (2017). Pengaruh penerapan fair value non current asset dan manajemen pajak atas asset perusahaan terhadap fee audit. Jurnal Riset Akuntansi Dan Keuangan, 4(3), 1229-1242. https://doi.org/10.17509/jrak.v4i3.5839.

Obeng, V. A., Ahmed, K., and Miglani, S. (2020). Integrated reporting and earnings quality: The moderating effect of agency costs. Pacific Basin Finance Journal, 60(February), 101285. https://doi.org/10.1016/j.pacfin.2020.101285.

Orman, C., and Köksal, B. (2017). Debt maturity across firm types: Evidence from a major 
developing economy. Emerging Markets Review, 30, 169-199. https://doi.org/10.1016/j.ememar.2016.12.001.

Palasari, D. (2018). Pengaruh penerapan fair value accounting terhadap indikasi manipulasi laporan keuangan. Universitas Negeri Padang, 6(2), 1-28.

Platikanova, P. (2017). Debt Maturity and Tax Avoidance. European Accounting Review, 26(1), 97-124. https://doi.org/10.1080/09638180.2015.1106329.

Rachmawati, N. A., and Martani, D. (2014). Pengaruh large positive abnormal book-tax differences terhadap persistensi laba. Jurnal Akuntansi Dan Keuangan Indonesia, 11(2), 120-137. https://doi.org/10.21002/jaki.2014.07.

Rey, A., Tuccillo, D., and Roberto, F. (2020). Earnings management and debt maturity: Evidence from Italy. Corporate Ownership and Control, 17(3), 179-186. https://doi.org/10.22495/cocv17i3art14.

Saksessia, D., and Firmansyah, A. (2020). The role of corporate governance on earnings quality from positive accounting theory framework. International Journal of Scientific and Technology Research, 9(1), 808-820.

Smith Jr, C. W., \& Warner, J. B. (1979). On financial contracting: An analysis of bond covenants. Journal of Financial Economics, 7(2), 117-161. https://doi.org/10.1016/0304-405X(79)90011-4.

Stacchezzini, R., Melloni, G., and Lai, A. (2016). Sustainability management and reporting: the role of integrated reporting for communicating corporate sustainability management. Journal of Cleaner Production, 136, 102-110. https://doi.org/10.1016/j.jclepro.2016.01.109.

Tesalonika, F. (2020). Kesiapan perusahaan untuk menerapkan pelaporan terintegrasi: penilaian laporan keberlanjutan perusahaan berdasarkan rerangka konseptual pelaporan terintegrasi [Widya Mandala Catholic University Surabaya]. https://repository.globethics.net/handle/20.500.12424/3869456.

Tlili, M., Othman, H. Ben, and Hussainey, K. (2019). Does integrated reporting enhance the value relevance of organizational capital? Evidence from the South African context. Journal of Intellectual Capital, 20(5), 642-661. https://doi.org/10.1108/JIC-02-20190034.

VanKhanh, V. T., and Hung, D. N. (2020). Impact of earnings quality on the debt maturity: The case of Vietnam. Asian Economic and Financial Review, 10(1), 1-12. https://doi.org/10.18488/journal.aefr.2020.101.1.12.

Venter, E. R., Stiglingh, M., and Smit, A. R. (2017). Integrated thinking and the transparency of tax disclosures in the corporate reports of firms. Journal of International Financial Management and Accounting, 28(3), 394-427. https://doi.org/10.1111/jifm.12064.

Vitolla, F., Raimo, N., and Rubino, M. (2019). Appreciations, criticisms, determinants, and effects of integrated reporting: A systematic literature review. Corporate Social Responsibility and Environmental Management, 26(2), 518-528. https://doi.org/10.1002/csr.1734.

Vourvachis, P., Woodward, T., Woodward, D. G., and Patten, D. M. (2016). CSR disclosure in response to major airline accidents: a legitimacy-based exploration. Sustainability Accounting, Management and Policy Journal, 7(1), 26-43. https://doi.org/10.1108/SAMPJ-12-2014-0080.

Wang, C. W., Chiu, W. C., and King, T. H. D. (2020). Debt maturity and the cost of bank loans. Journal of Banking and Finance, 112, 1-22. 
https://doi.org/10.1016/j.jbankfin.2017.10.008.

Wang, H., \& Zhang, J. (2017). Fair value accounting and corporate debt structure. Advances in Accounting, 37, 46-57. https://doi.org/10.1016/j.adiac.2017.02.002.

$\mathrm{Wu}$, J. (2017). An empirical study on value relevance of fair value : based on the data of financial industry and manufacturing industry in China. https://doi.org/10.20944/preprints201712.0055.v1.

Xie, B. (2016). Does fair value accounting exacerbate the procyclicality of bank lending? Journal of Accounting Research, 54(1), 235-274. https://doi.org/10.1111/1475679X.12103.

$\mathrm{Xu}, \mathrm{X}$., and Li, J. (2020). Asymmetric impacts of the policy and development of green credit on the debt financing cost and maturity of different types of enterprises in China. $\begin{array}{lllll}\text { Journal of Cleaner } & & \end{array}$ https://doi.org/10.1016/j.jclepro.2020.121574.

Zaro, E. S., Flores., Murcia, F. D.-R., Fasan, M., and Mio, C. (2020). The effect of the voluntary adoption of integrated reporting on the cost of equity: enforcement perspective. In XX USP International Conference in Accounting. https://congressousp.fipecafi.org/anais/20UspInternational/ArtigosDownload/2554.p df. 